\title{
Evaluasi Manajemen Pemasaran Di Sekolah Ar-Raudah Kota Bandar Lampung
}

\author{
Asmara Dewi ${ }^{1}$, Sovia Masayu ${ }^{2}$. \\ ${ }^{12}$ Fakultas Tarbiyah \& Keguruan, Universitas Islam Negeri Raden Intan Lampung \\ Email : dasmara254@gmail.com
}

\begin{abstract}
ABSTRAK:
Penelitian ini bertujuan untuk mengevaluasi pelaksanaan program Ar-Raudah Vaganza 2019 sebagai bagian dari kegiatan manajemen pemasaran di sekolah Ar-Raudah Kota Bandar Lampung. Pendekatan model yang digunakan adalah model CIPP (Context, Input, Process, Product). Metode pengumpulan data yang digunakan adalah observasi, wawancara, dan dokumentasi. Data yang terkumpul dari komponen context, input dan process dianalisis dengan menggunakan teknik kualitatif sedangkan untuk komponen product data yang terkumpul dianalisis dengan menggunakan deskriptif kuantitatif. Hasil penelitian adalah sebagai berikut : dari segi konteks yakni Ar-Raudah Vaganza 2019 sudah memiliki visi misi, kegiatan dan tujuan program yang sangat jelas. Dari segi masukan yakni komponen panitia penyelenggara sudah terpenuhi komponen peserta lomba tidak mencapai target yang telah ditetapkan. Komponen orang tua peserta lomba, tidak semua anak yang hadir didampingi orang tuanya dan hanya didampingi oleh gurunya saja, dan Komponen sarana prasana sudah tersedia lengkap sesuai dengan yang direncanakan sebelumnya. Selanjutnya, dari segi proses yaitu dalam komponen agenda kegiatan Ar-Raudah Vaganza 2019 sudah terlaksana dengan baik sesuai rencana. Dari segi hasil yakni minat, dari data hasil penelitian dapat disimpulkan bahwa baik peserta lomba maupun orang tua peserta lomba memiliki ketertarikan yang cukup tinggi terhadap SD Ar-Raudah, akan tetapi untuk data hasil penelitian mengenai komponen keinginan hanya peserta lomba yang memiliki persentase keinginan yang tinggi untuk mendaftar di SD Ar-Raudah sedangkan komponen keinginan dari orang tua peserta lomba mendapatkan persentase yang rendah dengan berbagai alasan.
\end{abstract}

Kata Kunci : evaluasi, Manajemen, CIPP

\section{ABSTRACT:}

This study aims to evaluate the implementation of the Ar-Raudah Vaganza 2019 program as part of marketing management activities in the Ar-Raudah school in Bandar Lampung city. Used is the CIPP (Context, Input, Process, Product) model. The method of data collection used is observation, interviews, and documentation. Data collected from context, input and process components are analyzed using qualitative techniques while for the product data components collected are analyzed by using quantitative descriptive. The results of the study are as follows : in terms of the context already have a very clear vision \& mission, activities and program objectives. In terms of the input, the component of the organizing committee have fulfilled the components of the race participants not achieving the targets that have already achieved the targets applied component parents of the contestants, not all children present are accompanied by their parents and only accompanied by theirteachers, and the facilities for infrastructure are fully available as planned beforehand. Furthermore in terms of the process, namely in the component of the Ar-Raudah Vaganza 2019event agenda, it has been carried out with both plans, in terms of product interests, from the research data it can be concluded that both the contest participants and the parents of the contest participants have there is a fairly high level of interest in Ar-Raudah elementary school, but for the research data, it is known that the desire component is only the contestant who has a high percentage of desires to enroll in Ar-Raudah elementary school while the desirecomponent of the parents of the contestant gets a low percentage with herbagal reason.

Keywords : evaluation, management, CIPP 


\section{PENDAHULUAN}

Evaluasi menjadi bagian yang sangat penting dan tak terpisahkan dari berbagai program atau kegiatan di suatu lembaga. Evaluasi mempunyai fungsi sebagai penyedia informasi untuk mengetahui tingkat keberhasilan sebuah program yang telah, sedang, atau akan dilaksanakan. Tanpa kehadiran evaluasi, tidak mungkin dapat ditemukan informasi mengenai kekurangan dan kelebihan dari aktifitas program tersebut.

Menurut Arikunto dan Cepi Safaruddin (2009 : 3) secara umum program dapat diartikan sebagai rencana. Herman dalam buku Tayibnapis (2000:9) mendefinisikan Program ialah segala sesuatu yang dicoba lakukan seseorang dengan harapan akan mendatangkan hasil atau pengaruh. program merupakan kesatuan kegiatan yang direncanakan dan disusun dengan baik agar rangkaian kegiatan menjadi terarah. Program juga sebagai salah satu sarana untuk mewujudkan cita-cita organisasi yang melibatkan sekelompok orang. Hakikatnya program harus benar-benar dirancang agar mencapai sasaran dan sesuai dengan tata aturan yang berlaku.

Tyler (2006 : 19) dalam Sudjana mendefinisikan evaluasi adalah proses untuk menetukan sejauh mana tujuan pendidikan dapat dicapai, dan upaya mendokumentasikan kecocokan antara hasil belajar peserta didik dengan tujuan program. Cronbach, Alkin dalam Sudjana (2006 : 19) juga menjelaskan bahwa evaluasi adalah kegiatan untuk mengumpulkan, memperoleh dan menyediakan informasi bagi pembuat keputusan. Seorang ahli yang sangat terkenal dalam evaluasi program bernama Stufflebeam (2009 : 2) mengatakan bahwa evaluasi merupakan proses penggambaran, pencarian dan pemberian informasi yang sangat bermanfaat bagi pengambil keputusan dalam menentukan alternatif keputusan.

Worthen dan Sanders dalam Sudjana (2006 : 20) mendefinisikan evaluasi program adalah suatu proses mengidentifikasi dan mengumpulkan informasi untuk membantu para pengambil keputusan dalam memilih berbagai alternative keputusan. Sejalan dengan pengertian di atas, Mugiadi dalam Sudjana (2006 : 21) mengartikan bahwa evaluasi program adalah upaya pengumpulan informasi mengenai suatu program, kegiatan atau proyek. Informasi tersebut berguna bagi pengambilan keputusan, antara lain untuk memperbaiki program, menyempurnakan kegiatan program lanjutan, menghentikan suatu kegiatan, atau menyebarluaskan gagasan yang mendasari suatu program atau kegiatan. Informasi yang dikumpulkan harus memenuhi persyaratan ilmiah, praktis, tepat guna, dan sesuai dengan nilai yang mendasari dalam setiap pengambilan keputusan.

Kata manajemen berasal dari bahasa prancis kuno menagement, yang artinya seni melaksanakan dan mengatur. Pengaturan dilaksanakan lewat proses dan diatur sesuai urutan dari fungsi-fungsi manajemen itu. Seni manajemen adalah pengetahuan bagaimana mencapai hasil yang diinginkan. Seni manajemen menginginkan kreativitas, atas dasar dan dengan syarat suatu pengertian mengenai ilmu manajemen. Oleh sebab itu, ilmu pengetahuan dan seni manajemen memilki komplemennya masing-masing. Manajemen pada 
umumnya dikaitkan dengan aktivitas-aktivitas perencanaan, pengorganisasian, pengendalian, penempatan, pengarahan, pemotivasian, komunikasi dan pengambilan keputusan yang dilakukan oleh setiap organisasi dengan tujuan untuk mengkoordinasikan berbagai sumber daya yang dimiliki oleh sebuah lembaga sehingga akan dihasilkan suatu produk atau jasa secara efisien (2016 : 10).

Seorang ahli dalam bidang manajemen Follet dalam L. Draft mengatakan bahwa manajemen sebagai sebuah seni artinya menyelesaikan pekerjaan melalui orang lain. Sejalan dengan hal tersebut pakar manajemen lainya yakni Haroold Koonts dan Cyril O Donnel, menyebutkan bahwa manajemen adalah usaha mencapai suatu suatu tujuan tertentu melalui kegiatan orang lain. Pakar manajemen lainnya yaitu Terry, berpendapat bahwa manajemen adalah suatu proses atau kerangka kerja, yang melibatkan bimbingan atau arahan dari kelompok orang-orang yang mengarahkan pada tujuan-tujuan organisasional atau maksud-maksud yang nyata. Sedangkan menurut Hasibuan (2016 : 11) manajemen adalah ilmu dan seni mengatur proses pemanfaatan sumbersumber lainnya secara efektif dan efisien untuk mencapai tujuan tertentu. Dengan kata lain dari uraian di atas dapat kita simpulkan bahwa manajemen adalah ilmu yang mengatur melalui orang lain yang terdiri dari tindakantindakan perencanaan, pengorganisasian, penempatan, pengarahan, pengendalian, pemotivasian dan pengambilan keputusan oleh setiap organisasi untuk mencapai tujuan tertentu.

Dalam Wikipedia dinyatakan bahwa pemasaran adalah suatu proses penyusunan komunikasi yang terpadu dan tujuannya untuk memberikan informasi tentang barang atau jasa yang diperjualbelikan yang kaitannya untuk memuaskan keinginan dan kebutuan masyarakat. Menurut Kotler dalam Usmara, pemasaran adalah suatu proses sosial dan manajerial yang didalamnya individu dan kelompok mendapatkan apa yang mereka butuhkan dan inginkan dengan menciptakan, menawarkan dan mempertukarkan produk dan nilai. Alexander Hiam dan Charles D. Schewe (2016 : 19) menyatakan bahwa pemasaran merupakan hasil dari seluruh kegiatan yang menjaga agar perusahaan selalu memperhatikan pelanggannya dan dengan manajemen yang baik, memastikan bahwa produk atau jasa yang ditawarkan perusahaan atau lembaga dihargai oleh pelanggannya. Sedangkan Stanton mengatakan, pemasaran adalah suatu sistem total dari kegiatan bisnis yang dirancang untuk merencanakan, menentukan harga, mempromosikan dan mendistribusikan barang-barang yang memuaskan keinginan dan jasa baik kepada para konsumen saat ini maupun konsumen potensial. Sehingga dapat disimpulkan bahwa pemasaran adalah proses pemberian informasi mengenai barang dan jasa melalui upaya menawarkan produk berupa barang atau jasa, menentukan harga dan mendistribusikannya kepada para konsumen.

Berdasarkan beberapa pemaparan di atas, maka dapat disimpulkan bahwa kegiatan evaluasi program manajemen pemasaran merupakan upaya dalam mengumpulkan dan menyediakan informasi yang dibutuhkan tentang berjalannnya serangkaian rencana kegiatan yang diselenggarakan oleh suatu 
instansi berupa analisis, perencanaan, pelaksanaan serta control programprogram yang telah direncanakan dalam hubungannya dengan pertukaranpertukaran yang diinginkan terhadap konsumen yang dituju untuk memperoleh keuntungan pribadi maupun bersama, serta membandingkan apa yang telah dicapai dari program dengan apa yang seharusnya dicapai berdasarkan standar yang telah ditetapkan. Adapun hasil informasi yang diperoleh dapat dijadikan bahan pertimbangan atau alternative dalam mengambil sebuah keputusan. Dengan kata lain dalam evaluasi program terdapat tahap-tahap atau proses yang bertujuan untuk mengumpulkan informasi sebagai usaha untuk mengetahui efektivitas komponen program dalam mendukung pencapaian tujuan program tersebut.

Salah satu Lembaga penyelenggara Pendidikan adalah sekolah Ar-Raudah yang berada di Kota Bandar lampung. Dalam penyelenggaraannya dibutuhkan sebuah manajemen pemasaran yang menjadi salah satu factor pendukung atas berlangsung program kegiatan lainnya yang telah direncanakan di sekolah tersebut. Salah satu program yang menjadi bagian dari manajemen pemasaran di sekolah ini adalah program Ar-Raudah Vaganza 2019, yang dalam pelaksanaannya tentunya terdapat beberapa masalah yang dipastikan akan menghambat tercapainya tujuan. Permasalahan bisa disebabkan oleh beberapa hal baik pada saat perencanaan ataupun pada saat pelaksanaan program, misalnya saja kurangnya faktor pendukung seperti sarana prasarana yang kurang memadai ataupun permasalahan dapat terletak pada sumber daya manusianya, dan lain sebagainya. Maka dari itu perlu adanya suatu evaluasi terhadap penyelenggaraan program Ar-Raudah Vaganza 2019 untuk mengetahui sejauh mana keberhasilan dari tercapainya tujuan program tersebut, agar selanjutnya dapat merumuskan strategi untuk pencapaian yang lebih baik dari program tersebut.

\section{METODE PENELITIAN}

Penelitian ini adalah penelitian evaluasi yang bertujuan untuk mengevaluasi program Ar-Raudah Vaganza 2019. Model evaluasi yang digunakan adalah Context, Input, Process, Product (CIPP) yang dikembangkan oleh stufflebeam dan shinkfield tahun 1985. Maksud diadakannya evaluasi adalah untuk mengetahui sejauh mana tujuan dari program tersebut sudah tercapai.

Pendekatan yang digunakan adalah kualitatif dan deskriptif kuantitatif. Penelitian dilaksanakan di Yayasan Mastal Musammid Bandar Lampung. Subjek dalam penelitian ini adalah sekolah Ar-Raudah Kota Bandar Lampung.

Sumber informasi yang digali yaitu panitia penyelenggara yang terdiri dari kepala sekolah dan guru-guru sekolah Ar-Raudah, calon siswa dan orang tua dari calon siswa.

Teknik pengumpulan data yang digunakan dalam penelitian ini adalah : observasi, wawancara dan dokumentasi. Data yang diperoleh dianalisis secara deskriptif kualitatif. 


\section{HASIL PENELITIAN}

\section{Analisis Context (Konteks)}

a) Latar Belakang Program Ar-Raudah Vaganza 2019

PG, TK, dan SD Ar-Raudah adalah lembaga pendidikan formal dibawah naungan Yayasan Mastal Musammid yang memiliki visi membentuk generasi islam masa depan yang ceria dan mandiri. Lembaga pendidikan islam berusaha menjawab tantangan dan memenuhi kebutuhan masyarakat untuk membentuk generasi masa depan rabbani, bermoral dan berakhlak islami serta mampu mengembangkan seluruh potensi anak baik mental maupun spiritual.

Untuk mencapai tujuan tersebut, PG, TK, dan SD Ar-Raudah memiliki beberapa program kegiatan yang dapat merealisasikan visi tersebut Dengan diadakannya rangkaian kegiatan dari program-program tersebut diharapkan, masyarakat luas dapat lebih mengenal PG, TK dan SD Ar-Raudah.

b) Deskripsi dan Tujuan Program Ar-Raudah Vaganza 2019

Adapun tujuan dari program Ar-Raudah Vaganza 2019 adalah sebagai berikut :

1) Menjalin Silaturahmi antar siswa, wali murid, dan guru dari sekolah lain.

2) Menggali, melatih dan mengaplikasikan potensi siswa dalam bidang seni, budaya dan tekhnologi.

3) Memenuhi kuota PPDB baik PG, TK, dan SD

4) Menjalankan Program Kerja Sekolah

5) Menarik minat masyarakat yang akan menyekolahkan putra putrinya baik PG, TK, dan SD.

Berdasarkan tujuan program Ar-raudah Vaganza 2019 yang sudah dipaparkan diatas, dapat dikatakan bahwa beberapa bagian dari tujuan telah terlaksana. Program Sekolah Berupa beberapa agenda yang bertujuan untuk mempromosikan sekolah Ar-Raudah telah terlaksana.akan tetapi untuk minat masyarakat berupa ketertarikan dan keinginan untuk mendaftar di Sekolah Ar-Raudah dari data hasil penelitian dapat dikatakan masih kurang tercapai, hal ini terlihat dari kurangnya minat dari calon siswa dan orang tua calon siswa yang hadir untuk mendaftar di Ar-Raudah, meskipun begitu dapat dikatakan bahwa pemenuhan kuota PPDB masih dapat dipenuhi.

Dari pemaparan diatas, dengan melihat besarnya persentase ketercapaian tujuan program, ramainya kehadiran dan antusiasme para peserta lomba dan orang tua yang hadir untuk mengikuti berbagai ajang perlombaan yang diselenggarakan oleh pihak panitia penyelenggara dapat disimpulkan bahwa program Ar-Raudah Vaganza 2019 masih sangat potensial untuk dilaksanakan lagi pada waktu yang akan datang, hanya saja harus dipertimbangkan lagi untuk waktu pelaksanaannya, akan lebih potensial untuk dapat mencapai berbagai tujuan yang telah 
ditetapkan secara keseluruhan apabila program ini diadakan pada awal semester ganjil.

\section{Analisis Input (Masukan)}

a) Penyelenggara Program

Penyelenggara program Ar-Raudah Vaganza 2019 terdiri dari 78 orang guru PG, TK, dan SD Ar-Raudah yang memiliki karakteristik dan latar belakang pendidikan dan budaya yang berbeda-beda. Dengan demikian keseluruhan dari guru yang ada di sekolah Ar-Raudah telah ikut berpartisipasi dalam program Ar-Raudah Vaganza 2019.

\section{b) Calon Siswa dan Orang Tua Calon Siswa}

Penyelenggara menargetkan calon siswa untuk PG dan TK Ar-Raudah adalah anak usia 4-6 tahun yang berada di sekitar wilayah kota Bandar Lampung, akan tetapi pada prosesnya hanya beberapa wilayah dari kota Bandar Lampung yang anak usia dininya mendaftar di PG dan TK Arraudah. Sedangkan untuk SD Ar-Raudah penyelenggara menargetkan anak-anak dari TK dan PG Ar-Raudah serta dari alumni TK lainnya yang berada di wilayah Bandar Lampung, dan pada prosesnya tidak semua alumni PG dan TK Ar-Raudah serta tidak semua alumni dari TK lain yang berada di wilayah kota Bandar Lampung mendaftar di SD Ar-Raudah, dengan berbagai alasan salah satunya, jarak antara sekolah dan rumah calon siswa yang terlalu jauh .

\section{c) Sarana dan Prasarana}

Sarana dan prasaran merupakan salah satu hal yang penting dalam menunjang keberlangsungan proses sebuah kegiatan. Kelengkapan sarana dan prasarana yang telah direncanakan oleh panitia penyelenggara tak dapat dipungkiri menjadi salah satu factor penentu dalam kelancaran sebuah kegiatan. Demikian pula halnya dengan program manajemen pemasaran di sekolah Ar-Raudah, penyelenggara telah merencanakan berbagai sarana dan prasarana yang akan digunakan dalam berbagai kegiatan yang akan dilangsungkan.

Dari data yang diperoleh dapat dilihat bahwa pihak penyelenggara telah dapat memenuhi keseluruhan dari sarana dan prasarana yang telah direncanakan untuk dipergunakan dalam berbagai kegiatan yang ada di program Ar-Raudah Vaganza 2019.

\section{Analisis Process (Proses)}

\section{a) Agenda Kgiatan Program Ar-Raudah Vaganza 2019}

Pada program Ar-RaudahVaganza 2019 terdapat berbagai agenda kegiatan. Dari data yang diperoleh dapat dikatakan bahwa keseluruhan dari agenda kegiatan yang telah direncanakan oleh pihak penyelenggara telah dapat terlaksana.

\section{Analisis Product (Hasil)}

\section{a) Penilaian Kesiapan Panitia}

Berdasarkan input dan process pada Program Ar-Raudah vaganza 2019, dan dari data yang diperoleh melalui wawancara dan observasi mengenai kesiapan penyelenggara, maka dapat dikatakan bahwa kesiapan 
penyelenggara dalam menyiapkan berbagai sarana dan prasarana yang digunakan pada saat pelaksanaan program Ar-Raudah Vaganza 2019 berlangsung adalah sebesar $100 \%$, sedangkan kesiapan penyelenggara dalam pelaksanakan berbagai agenda kegiatan yang ada di dalam program manajemen pemasaran Ar-Raudah adalah sebesar 100\%, dan kesiapan penyelenggara dalam mengikuti setiap proses yang berlangsung dalam agenda kegiatan adalah sebesar $71 \%$. Untuk lebih jelasnya dapat dilihat pada diagram dibawah ini :

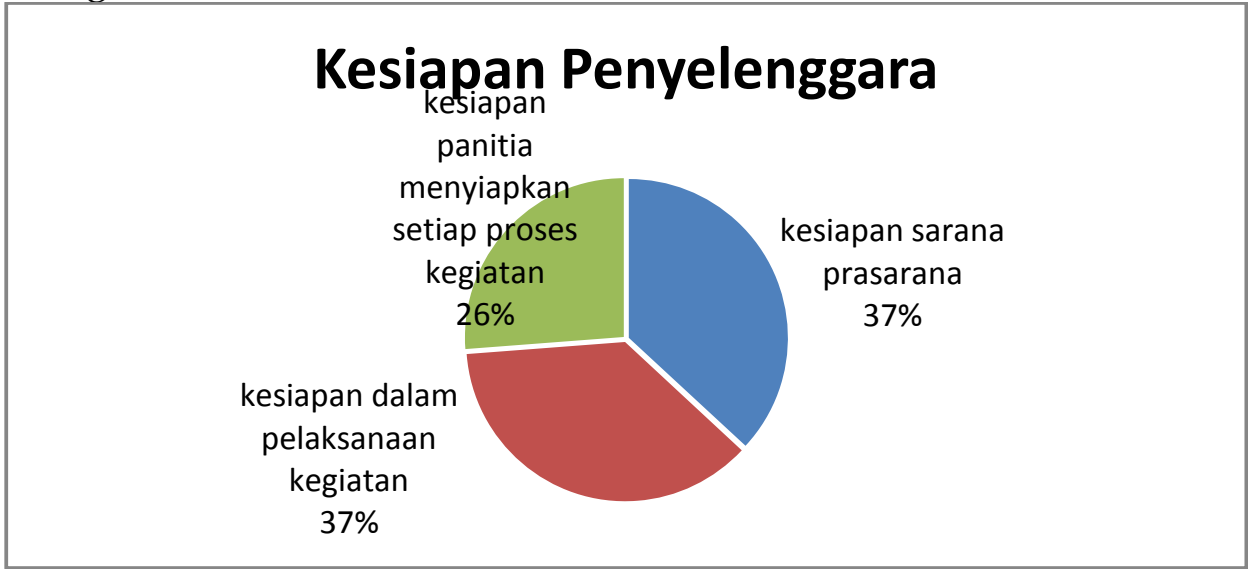

b) Penilaian Minat

Kesiapan Penyelenggara

\section{1) Peserta Lomba}

Berdasarkan hasil wawancara dengan anak-anak yang merupakan calon siswa di sekolah Ar-raudah maka diperoleh hasil persentase minat yang dibagi menjadi ketertarikan terhadap sekolah Ar-Raudah dan keinginan untuk mendaftar di sekolah Ar-Raudah sebagai berikut :

a) Penilaian Ketertarikan Peserta Lomba

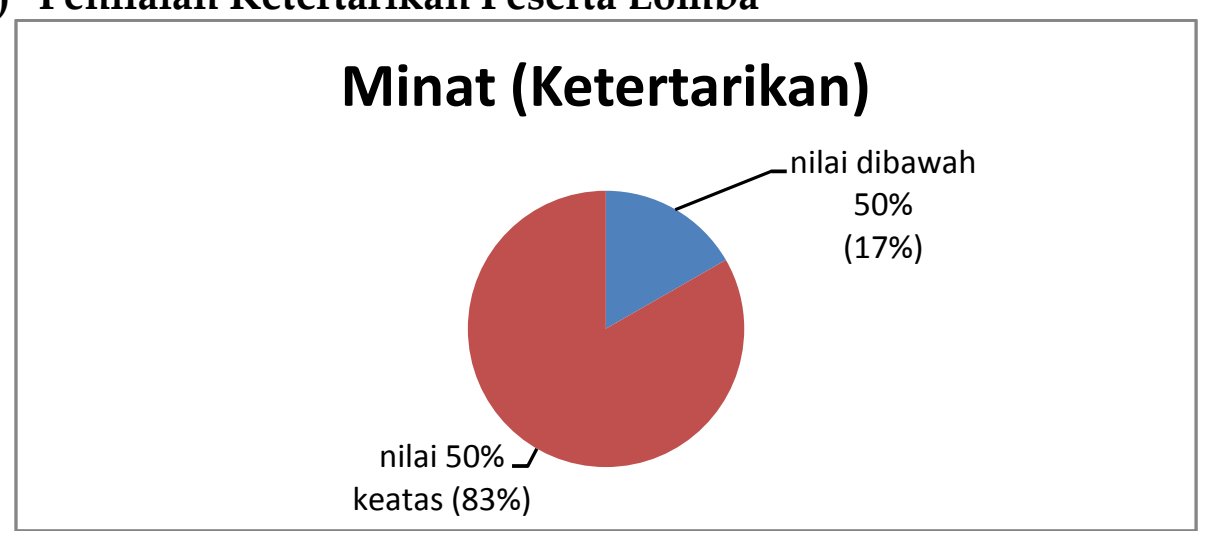

\section{Minat (Ketertarikan)}

Dari gambar diatas dapat kita lihat bahwa persentase ketertarikan dari calon siswa yang berada di atas angka $50 \%$ sebesar $83 \%$ sedangkan untuk yang nilainya dibawah $50 \%$ persentase berada diangka $17 \%$ saja, hal ini menunjukkan bahwa ketertarikan para calon siswa peserta lomba terhadap program Ar-Raudah Vaganza 2019 sangat besar. Dari enam pertanyaan wawancara yang diajukan mengenai ketertarikan peserta lomba, point pertanyaan nomor 2 yaitu tentang alasan calon 
siswa mengikuti kegiatan promosi pemasaran, apakah karena ajakan teman ataukah keinginan sendiri mencapai persentase terendah sebesar $55,55 \%$, hal ini menunjukkan bahwa lebih dari setengah calon siswa mengikuti kegiatan ini atas keinginan sendiri dan bukan karena terpengaruh oleh ajakan orang lain. Sedangkan untuk lima pertanyaan lainnya persentase mencapai nilai $88,88 \%$ hingga $100 \%$, dengan demikian dapat disimpulkan bahwa program manajemen pemasaran di sekolah Ar-Raudah sangat diminati oleh para calon siswa.

b) Penilaian Keinginan

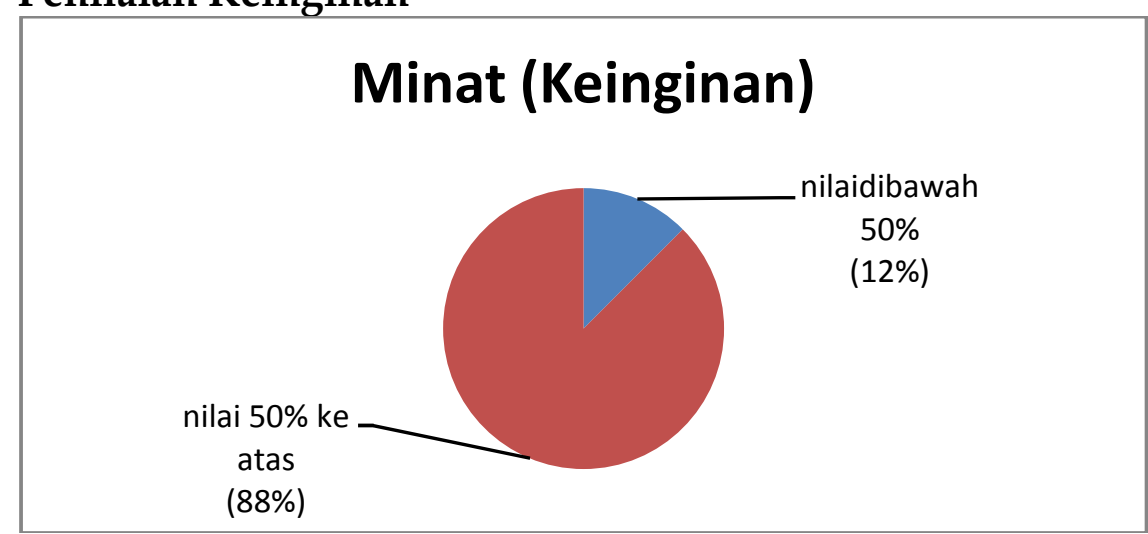

Minat (keinginan)

Dari gambar diatas dapat kita lihat bahwa persentase ketertarikan calon siswa yang berada di atas angka $50 \%$ sebesar $88 \%$ sedangkan untuk yang nilainya dibawah $50 \%$ persentase berada diangka $12 \%$ saja, hal ini menunjukkan bahwa keinginan para calon siswa untuk bersekolah di Ar-Raudah sangat besar. Dari delapan pertanyaan wawancara yang diajukan mengenai keinginan calon siswa, point pertanyaan nomor 4 yaitu tentang alasan calon siswa ingin mendaftar di sekolah Ar-Raudah, apakah karena dorongan orang lain mencapai persentase terendah sebesar $35,71 \%$, hal ini menunjukkan bahwa kebanyakan dari peserta lomba memiliki keinginan untuk bersekolah di Ar-Raudah. Sedangkan untuk tujuh pertanyaan lainnya persentase mencapai nilai $50 \%$ hingga $100 \%$, dengan demikian dapat disimpulkan bahwa sekolah Ar-Raudah cukup diminati oleh para calon siswa.

\section{c) Penilaian Minat Per-anak (Ketertarikan \& Keinginan) Peserta Lomba}




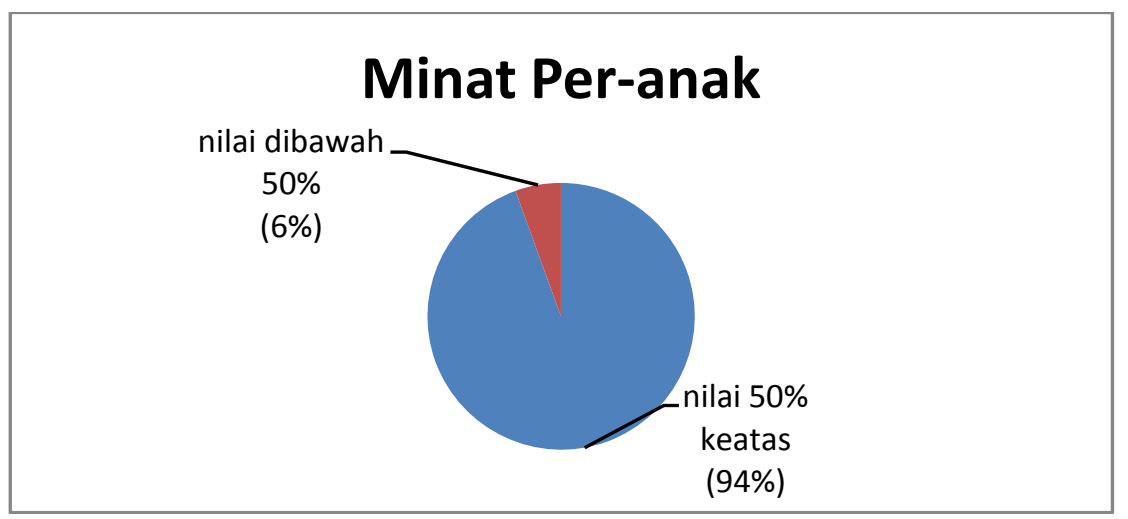

\section{Minat per-anak}

Dari gambar diatas dapat kita lihat bahwa persentase minat peranak (ketertarikan \& Keinginan) dari peserta lomba yang berada di atas angka $50 \%$ sebesar $94 \%$ sedangkan untuk yang nilainya dibawah $50 \%$ persentase berada diangka $6 \%$ saja, hal ini menunjukkan bahwa minat (ketertarikan \& keinginan) para peserta lomba terhadap program Ar-Raudah Vaganza 2019 dan SD Ar-Raudah sangat besar. Dari delapan belas orang sampel yang diwawancara, hanya satu orang yang mendapat $42,85 \%$, empat orang dengan nilai $50 \%$, empat orang dengan nilai $57,14 \%$, dua orang dengan nilai $78,57 \%$, dua orang dengan nilai 85,71\%, dan lima orang dengan nilai $100 \%$ dengan demikian dapat disimpulkan bahwa SD Ar-Raudah sangat diminati oleh para peserta lomba.

\section{2) Orang Tua Peserta Lomba}

Berdasarkan hasil wawancara dengan orang tua calon siswa pada program Ar-Raudah Vaganza 2019 ini maka diperoleh hasil persentase minat yang dibagi menjadi ketertarikan terhadap sekolah Ar-Raudah dan keinginan untuk mendaftar di sekolah Ar-Raudah sebagai berikut :

a) Penilaian Minat (Ketertarikan \& Keinginan) Orang Tua Peserta Lomba

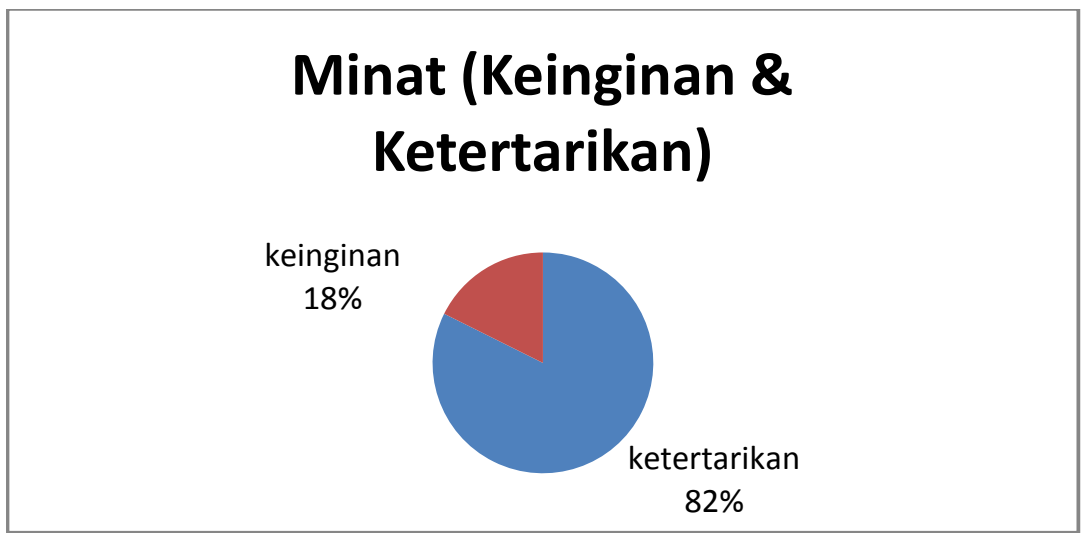

Minat (Ketertarikan)

Dari gambar diatas dapat kita lihat bahwa persentase minat (ketertarikan \& Keinginan) dari orang tua calon siswa, untuk point ketertarikan sebesar $82 \%$ sedangkan untuk point keinginan persentase 
hanya sebesar $18 \%$ saja, hal ini menunjukkan bahwa orang tua peserta lomba sangat tertarik terhadap program manajemen pemasaran di sekolah Ar-Raudah, akan tetapi dengan berbagai alasan keinginan untuk mendaftarkan anaknya di sekolah Ar-Raudah masih sangat kurang.

b) Penilaian Minat per-orang (Ketertarikan \& Keinginan) Orang Tua Peserta Lomba

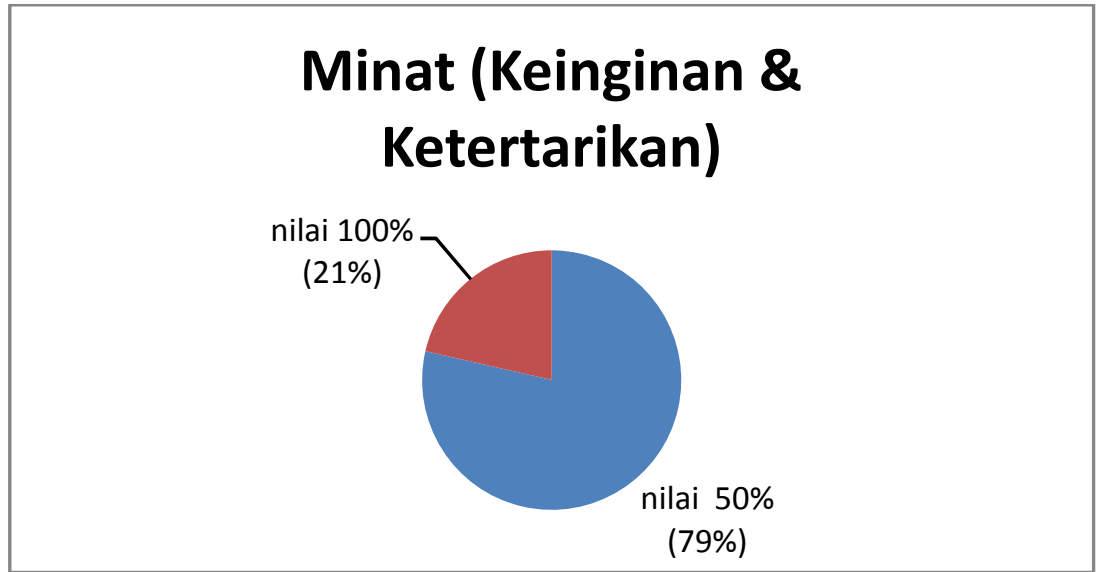

Minat (keinginan \& Ketertarikan)

Dari gambar diatas dapat kita lihat bahwa persentase minat perorang (ketertarikan \& Keinginan) dari orang tua calon siswa yang berada diangka $50 \%$ sebesar $79 \%$ sedangkan untuk yang nilainya $100 \%$ berada diangka $21 \%$ saja, hal ini menunjukkan bahwa minat (ketertarikan \& keinginan) para calon siswa terhadap program kegiatan promosi di sekolah Ar-Raudah masih kurang. Dari empat belas orang sampel yang diwawancara, yang mencapai nilai 50\% adalah sebanyak sebelas orang, sedangkan yang mendapatkan nilai sebesar $100 \%$ hanya tiga orang saja. dengan demikian dapat disimpulkan bahwa dengan berbagai alasan sekolah Ar-Raudah masih kurang diminati oleh orang tua calon siswa.

Untuk melakukan analisis ketercapaian evaluasi program manajemen pemasaran digunakan rumus sebagai berikut :

\section{KESIMPULAN}

$$
\frac{\text { Nilai diperoleh }}{\text { Nilai tertinggi }} \times 100
$$

Berdasarkan analisa terhadap masalah penelitian maka dapat disimpulkan bahwa secara umum program Ar-Raudah Vaganza 2019 dilaksanakan dengan baik meskipun masih terdapat beberapa aspek yang masih perlu untuk ditingkatkan.

Pada aspek context (konteks) yakni Ar-Raudah Vaganza 2019 sudah memiliki visi misi, kegiatan dan tujuan program yang sangat jelas sebagaimana termuat didalam dokumen berupa proposal kegiatan. Pada 
aspek input (masukan) yakni komponen penyelenggara sudah terpenuhi sebagaimana yang tercantum pada proposal kegiatan dan penyelenggara dinyatakan sepenuhnya siap melaksanakan kegiatan program Ar-Raudah Vaganza 2019, komponen calon siswa dan orang tua calon siswa tidak mencapai target yang telah ditetapkan dengan berbagai alasan, dan Komponen sarana prasana sudah tersedia lengkap sesuai dengan yang direncanakan sebelumnya. Selanjutnya, dalam aspek process (proses) yaitu dalam komponen agenda kegiatan program Ar-Raudah Vaganza 2019 sudah terlaksana dengan baik sesuai rencana. Pada aspek product (hasil) yakni minat, dari data hasil penelitian dapat disimpulkan bahwa baik calon siswa maupun orang tua calon siswa memiliki ketertarikan yang cukup tinggi terhadap sekolah Ar-Raudah, akan tetapi untuk data hasil penelitian mengenai komponen keinginan hanya calon siswa yang memiliki persentase keinginan yang tinggi untuk mendaftar di sekolah Ar-Raudah sedangkan komponen keinginan dari orang tua calon siswa mendapatkan persentase yang rendah dengan berbagai alasan.

\section{DAFTAR PUSTAKA}

Abd Rozak dan Maifalinda Fatra, 2012, Perangkat \& Evaluasi Pembelajaran, Ciputat : FITK UIN Jakarta.

Anas Sudijono, 2007, Pengantar Evaluasi Pendidikan, Jakarta : PT Raja Grafindo.

Anggio Linnando, Evaluasi program pembelajaran pendidikan jasmani di sekolah menengah pertama negeri kabupaten solok, diakses dari http://ppjp.unlam.ac.id/pdf.

Djudju Sudaja, 2006, Evaluasi Program Pendidikan Luar Sekolah, Bandung : PT Remaja RosdaKarya.

Eko Putro Widoyoko, 2015, Evaluasi Program Pembelajaran, Yogyakarta : Pustaka Pelajar.

Eko Putro Widoyoko, Evaluasi Program Pembelajaran, 2017, (EP Widoyoko2009-academia.edu)

Farida Yusuf Tayibnapis, 2000, Evaluasi Program, Jakarta : Rineka Cipta.

Hadi Sutrisno, 1985, Metodelogi Research, Yogyakarta.

Jejen Musfah, 2011, Peningkatan Kompetensi Guru Melalui Pelatihan dan Sumber Belajar Teori dan praktik, Jakarta: Kencana.

John M. Echols, 2016, Kamus Inggris - Indonesia, Jakarta: PT Gramedia Pustaka Utama.

Moloeng, Lexy, 2008, Metodologi Penelitian Kualitatif Bandung : PT. Rosdakarya.

Nana Sudjana, 2004, Dasar-Dasar Proses Belajar Mengajar, Bandung : Sinar Baru Algesindo.

Nurahyuningsih, Evaluasi Pelaksanaan Program, diakses dari http://eprints.uny.ac.id/.pdf. 
Pupuh Fathurrohman dan Sobry Sutikno, 2010, Strategi Belajar Mengajar: Melalui Penanaman Konsep Umum dan Konsep Islami, Bandung: PT Refika Aditama.

Sudaryono, 2012, Dasar-Dasar Evaluasi Pembelajaran, Yogyakarta : Graha Ilmu.

Suharsimi Arikunto, 2002, Prosedur Penelitian (Suatu Pendekatan Praktek), Rineka Cipta, Jakarta.

Suharsimi Arikunto, 2006, Dasar-Dasar Evaluasi Pendidikan, Jakarta : Bumi Aksara.

Suharsimi Arikunto dan Cepi Safaruddin, 2009, Evaluasi Program Pendidikan : Pedoman Teoritis Praktis Bagi Mahasiswa dan Praktisi Pendidikan, Jakarta: Bumi Aksara.

Sukardi, 2011, Evaluasi Pendidikan Prinsip E Operasionalnya, Jakarta: Bumi Aksara.

Sumadi Suryabrata, 2013, Metodologi Penelitian, (PT. Raja Grafindo Persada, Jakarta.

Undang-Undang Republik Indonesia Nomor 20 Tahun 2003 Tentang Sistem Pendidikan Nasional

Uyu Wahyudin, Mubiar, 2010, Penilaian Perkembangan Anak Usia Dini, CV. Falah Production : Bandung.

Wirawan, 2012, Evaluasi: Teori, Model, Standar, Aplikasi dan Profesi, Depok: Rajawali Pers.

Zainal Arifin, 2009, Evaluasi Pembelajaran, (Jakarta: Direktorat Jenderal Pendidikan Islam. 